\title{
Do International Football Match and Host Country Impact Stock Return in Indonesia?
}

\author{
Adrianna Syariefur Rakhmat \\ Pelita Bangsa University, Indonesia \\ \{adriannasyariefur@pelitabangsa.ac.id\}
}

\begin{abstract}
This research is an analysis to find out about effect of football match and Host Country on Stock Return in Indonesia Stock Exchange. This study focuses on the specific football championship including ASIAN Football Cup, ASIAN GAMES, SEA GAMES, and AFF CUP for the period from 1996 until 2019. The tool used in this research is EVIEWS data analytics software and its multiple regression analysis specially. Variable included in the regression model are football match, host country, and stock price. The result of this study showed that stock return in Indonesia does not influenced by football match and host country.
\end{abstract}

Keywords: Football Match, Host Country, Stock Return

\section{Introduction}

The big capacity of football stadium in Indonesia caused the number of football's supporter in Indonesia more than other sport. Based on the result of Indonesia Survey Scale, the football is number one most popular sport in Indonesia after Badminton and Volleyball. The football can attract more people come to the stadium to support their clubs and national team. More people come to football event or other sports will add economic value of the event. The effect of sport including football in increasing economy of the country can be explained by the sport expenditure from government and households. it summarize the amount spent by households in sporting goods and services with state government sport budget, sport expenditure by sport local authorities, sport sponsorship expenses, and TV Broadcasting rights raised by sport event organizers [3].

Considering football has an economic impact on a country, and also stock market is an economic indicator, and in the recent year there is one club of Indonesian Football League is listed in the stock exchange; therefore there is discussion about team's performance impact on stock return. Beside this, according to international football event which take place in Indonesia can attract more peope including domestic and international supporters; therefore there is discussion about host country impact on stock return.

Previous studies reported that the results about impact of team's performance on stock return are different. Some studies explained the effect of team's performance was positive. It is refer to [8], there is positive effect of draws on Benfica's and Ajax's stock return. The other empirical evidence presented here suggests that Besiktas's win against foreign rivals in the Winner's Cup increases stock market return [4]. As well as research carried out by [15], the sport sentiment is effective in Turkish Market and sport as determinant variable of individual moods. Additionaly, related to the championship of the Portugal League, we found that whenever the team wins the national championship share prices always presented a positive return [6]. Some studies described the effect was negative. It is related to [8] that is negative effect of draws and loses on 
Juventus stock return. While in the research of [7], there is significant decline of market after soccer loses. While other studies described there is no significant effect between team's performance and stock return. According to [12] sport result might not affect investors enough to induce higher return than normal. The result of studies from [2], there is not significant effects on the Brazilian stock market following football matches, while the result from [8] no effects reported for Porto Club on stock return. With the same result found in Zagreb Stock Exchange [16], which is no significant effects of winning or losing a football match, even when controlling for game being friendly, competitive tournament or qualification one. And also that no profitable trading strategies could be obtained around the football match day. Indeed, a result from [9] that a most European club's stock return are influenced by the financial context such as profit, but according to [14] that in English Football the financial performance correlated to sporting performance. Even the World Cup's effect on the United States Market is probably unknown at the present time and it is possible that investor will find understanding this phenomenon by exploting some financial devices [10].

About the correlation between host country and stock return, there some studies explaining the different result. The summer games represent a larger event and then more likely to have a significant impact [5]. The another result showed well performance of stock market for the Greece regarding the Summer Olympic Games, South Korea regarding the 2002 FIFA World Cup, Portugal regarding the 2004 European Football Championships and United States regarding 1996 Summer Olympic Games. On the other hand, in the following countries the stock market performed badly in the year when they hosted the particular event: Japan regarding 1998 Winter Olympic Games and 2002 FIFA world cup, German regarding 1988 European Fooball Championship, Belgium regarding the 2000 European Football Championship, and United States regarding the 2002 Winter Olympic Games [11]. While the announcement impact of hosting FIFA World Cup on the stock market of the host country is founded that positive trend in stock return for South Africa while Japan showed a decline stock return. It is founded also that most countries show insignificant negative cumulative abnormal stock return. There are however few example where stock markets show positive cumulative abnormal stock return, with significant result [13].

This research is different from other studies where nobody has ever analyzed Indonesia about correlation between sporting performance, host country and stock return. This research focused on international football event where Indonesia joined there such as ASEAN Football Championship, ASIAN GAMES, SEA GAMES, and ASEAN Football Federation (AFF) Championship for the period 1996 to 2019.

\section{Methodology}

This research is based on secondary data which collected from various sourced such as journals and websites. The discussion in this research indicates that stock return should be influenced by football match and host country. The football match mentioned before means the result of the match including win, lose, and draw. When a team won a match, it will be scored 3 (three) + number goal scored by the team. When a team drew a match, it will be scored 2 (two) + number goal scored by the team. When a team loose a match, it will be scored 1 (one) + number goal scored by the team.

While host country mentioned above means when Indonesia became host of ASIAN Football Championship, ASIAN GAMES, SEA GAMES, and ASEAN Football Federation (AFF) 
Championship. When Indonesia became host of international football event, it will be valued at 1(one). When Indonesia did not become host of international football event, it will be valued at 0 (zero). This research is analyzed by multiple regreesion with stock return as independent variable, team's performance and host country as dependent variable. Then the formulation to be fitted is :

$$
R_{t}=\beta_{1} F M+\beta_{3} D H C+\varepsilon t
$$

Where $\mathrm{R}$ is the stock return, FM is variable for Football Match that takes, and DHC is dummy variable for Host Country that take value 1 when Indonesia was a host country of International Football Event.

\section{Empirical Research}

Dependent Variable: Y1

Method: Least Squares

Date: 07/12/20 Time: 11:30

Sample: 182

Included observations: 81

\begin{tabular}{ccccc}
\hline Variable & Coefficient & Std. Error & t-Statistic & Prob. \\
\hline C & 1.441895 & 0.216170 & 6.670179 & 0.0000 \\
X1 & -0.055698 & 0.044411 & -1.254132 & 0.2135 \\
X2D & 0.132613 & 0.288278 & 0.460018 & 0.6468 \\
R-squared & 0.021707 & Mean dependent var & 1.245988 \\
Adjusted R-squared & -0.003377 & S.D. dependent var & 1.029918 \\
S.E. of regression & 1.031655 & Akaike info criterion & 2.936540 \\
Sum squared resid & 83.01637 & Schwarz criterion & 3.025223 \\
Log likelihood & -115.9299 & Hannan-Quinn criter. & 2.972121 \\
F-statistic & 0.865371 & Durbin-Watson stat & 1.646193 \\
Prob(F-statistic) & 0.424897 & & \\
\hline
\end{tabular}

Based on the result we can conclude that stock return in Indonesia does not influenced by football match and host country. Then there is no effective investment strategy based on sport variable regarding the Indonesian Stock Market.

\section{Limitation}

This study needs to be further explored and investigated because this study still has no relationship between stock return, football match and host country. In addition, the financial performance of Indonesia Football Federetion can aslo be a mediator variable between host country variable and stock return. On the other hand, the financial performance can be added as an independent variable in this research. 


\section{References}

[1] Andreff, W. : Globalization of the Sport Economy. Rivista Diritto ed Economia Dello Sport. Vol. 4, p. 13-32 (2008)

[2] Bankers, P. : The Impact of National Footbal Result on Stock Prices. Master Thesis in Finance. Tillburg School of Economics and Management (2014)

[3] Bell, AR., Brooks, C., Matthews, D., \& Sutcliffe, C. : Over The Mood or Sick as a Parrot ? The Effects of Football Results on Club's Share Price. ICMA Centre Discussion Papers in Finance. University of Reading (2009)

[4] Berument, H., Ceylan, NB., \& Gozpinar E. : Performance of Soccer on The Stock Market Evidence From Turkey. The Social Science Journal. Vol 43, pp. 695-699(2006)

[5] Dick, CD., \& Wang, Q. : The Economic Impact of Olympic Games : Evidence from Stock Markets. Discussion Paper. Centre for European Economic Research (2008)

[6] Duque, J., \& Ferreira, NA. : Explaining Share Price Performance of Football Clubs Listed on The Euronext Lisbon. Working Paper. Instituto Superior de Econmia e Gestao (2005)

[7] Edmans, A., Garcia, D., \& Norli, O. : Sport Sentiment and Stock Return. The Journal of Finance. Vol. 62, pp. 1967-1998 (2007)

[8] Floros, C. : Football and Stock Return : New Evidance. Procedia Economics and Finance. PEF 14, pp. 201-209 (2014)

[9] Gimet, C., \& Montchaud, S. : What Drives European Football Club's Stock Return and Volatility. International Journal of the Economics of Business (2006)

[10] Kaplanski, G., \& Levy, H. : Exploitable Predictable Irrationality : The FIFA World Cup Effect on the US Stock Market. Journal of Financial and Quantitative Analysis. Vol 45, p. 535-553(2010)

[11] Li, X. : The Impact of Mega Sporting Events on Stock Markets. Dissertation. Auclanad University of Technology (2007)

[12] Lidemar, A., \& Karlson, L. : The Effect of Sport Result on Domestic Stock Market Indices. Master Thesis in Economic and Business Administration. Copenhagen Business School(2014)

[13] Ramdas, B., Gaalen, RV., \& Bolton, J. : The Announcement Impact of Hosting the FIFA World Cup on Host Country Stock Markets. Procedia Economics and Finance. Vol. 30, pp. 226-238 (2015)

[14] Samagio, S., Couto, E., \& Caiado J. : Sporting, Financial and Stock Market Performance in English Football : An Empirical Analysis of Structural Relationship. Working Papers. Centre for Applied Mathematics and Economics (2009)

[15] Sevil, T., \& Polat, A. : Sport Sentiment and Stock Market Returns : An Evidence of National Match Days in Turkey. International Journal of Economics, Commerce and Management. Vol. 3, pp. 1-9 (2015)

[16] Skrinjaric, T., \& Barisic, P. : Effect of Football Match Result of Croatioan National Team on Stock Return : Evidence from Zagreb Stock. Zagreb International Review of Economics and Business. Vol. 2, pp. 13-45 (2019) 